\title{
USE OF PILOT TUNNEL METHOD TO OVERCOME DIFFICULT GROUND CONDITIONS IN KARAVANKE TUNNEL
}

\section{UPOTREBA METODOLOGIJE PROBNOG TUNELA ZA PREVAZILAŽENJE TEŠKIH USLOVA GRADNJE U TUNELU KARAVANKE}

\author{
Vojkan JOVIČıĆ
}

PREGLEDNI RAD

REVIEW PAPER

UDK: $624.191 .1(497.4)$

doi:10.5937/GRMK1801037J

\section{INTRODUCTION}

The tunnel Karavanke is some $7,9 \mathrm{~km}$ long single tube tunnel, which is located at European corridor 10, European motorway road E61. It is the only remaining tunnel at the corridor 10 and also at the Slovenian network of motorways, which provides for the traffic in both directions in a single tube. As such, the tunnel is in breach of the directive of European Council 2004/54/ESof 2004. According to the directive, each tunnel longer than $1000 \mathrm{~m}$ must have an escape route in the form of evacuation adit or the second tube, which can be also used for single way traffic.

The tunnel presents the most frequent traffic link between Slovenia and Austria. It is the last and the longest tunnel on the northern arm (Ljubljana Jesenice) of the Slovenian motorway network. In historical terms the tunnel plays a significant role in connecting the Middle with Southern Europe as the link passes beneath some $2500 \mathrm{~m}$ high Karavanke chain of mountains. Approximately half of the tunnel, that is some $3,5 \mathrm{~km}$, is on the Slovenian side, the rest is in Austria.

As will be explained in some detail, the construction of the first tube, which took place some 30 years ago, was met with many challenges. These challenges will remain for the construction of the second tube but will take different and sometimes more demanding forms. The main challenges for the construction of the second tube are summarised as follows: a) large convergence displacements in squeezing rock conditions, and b) the huge inflows of water during the excavation. Both of these

Vojkan Jovičić, Ph.D. C.E.

IRGO Consulting d.o.o.

Slovenčeva 93, 1000 Ljubljana, Slovenia

e-mail: vojkan.jovicic@irgo.si challenges can be reasonably addressed by the use of the pilot tunnel method, which in this case provides several advantages in the comparison to the traditional NATM (New Austrian Tunnelling Method) division of the tunnel to top heading, bench and invert.

\section{PILOT TUNNEL METHOD}

The pilot tunnel method is based on a construction of a small-diameter tunnel, which is driven parallel to the axis of a much larger main tunnel. Pilot tunnel can be located near the crown, bench, invert, or rarely outside the layout of the main tunnel to provide access to critical locations.

The main purposes of the pilot tunnel method are numerous and are summarised as follows: a) investigating the nature and behaviour of rock mass, b) exploring adequate excavation techniques, c) introducing new support procedures, d) treating or improving the ground prior to construction of the main tunnel, e) dewatering of the rock mass, f) enabling gradual stress relief for control of displacements and others. Pilot tunnels are used primarily in difficult ground conditions, in which this method is proved to be very useful. Kavadass (1999) reports successful use of the method for the ground pre-treatment with a Tube-a Manchette grouting from a pilot tunnel ahead of the tunnel face in Athens metro. The method, schematically presented in Figure 1, was successful in drastically reducing ground settlements and was used extensively during the construction of underground metro stations where the tunnels passed below buildings of the Old City of Athens. 

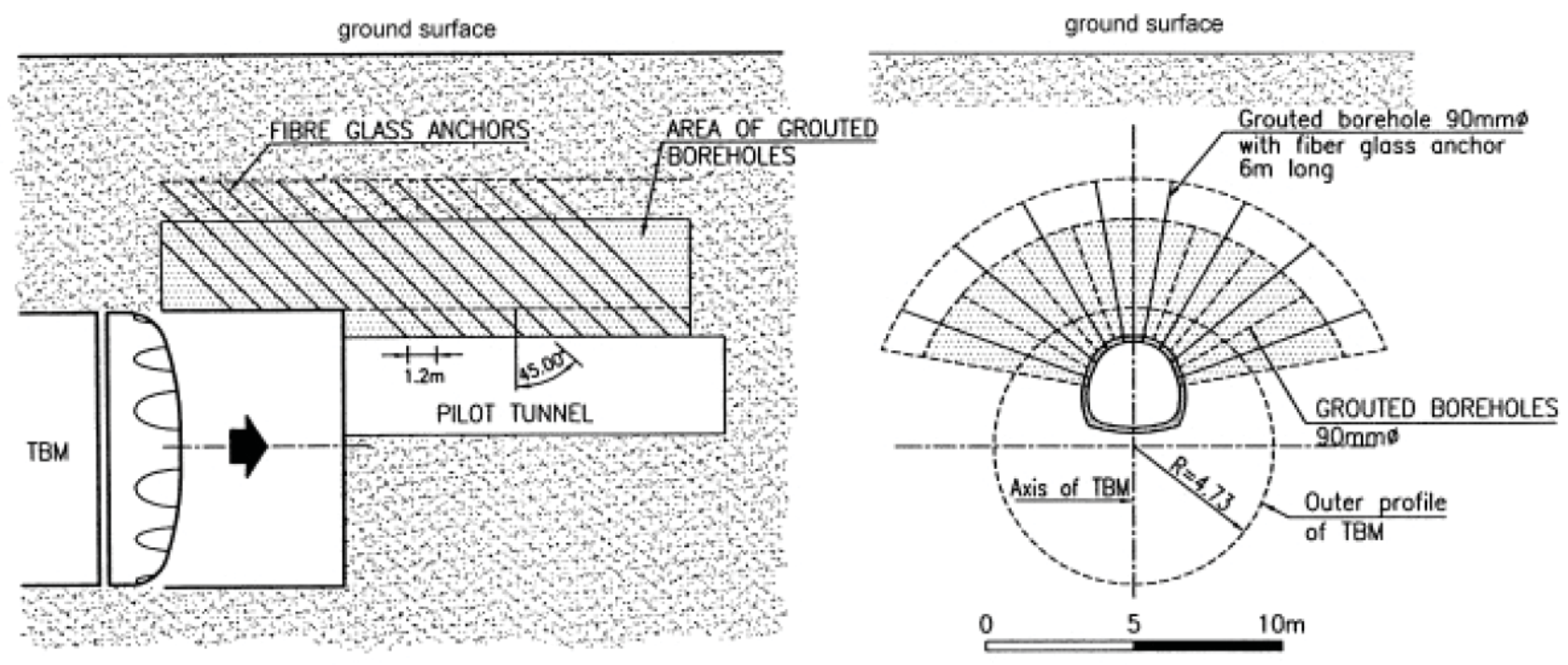

Figure 1. Ground pre-treatment from a pilot tunnel in the Athens metro (after Kavvadas, 1999)

As it will be explained in continuation, during the construction of the second tube of Karavanke tunnel there would be difficult sections in which the use of pilot tunnel would be necessary and fully justified. These are the conditions expected firstly in the zone of squeezing rock and secondly in the zones of the crossing of the aquifers, in which the large inflows of water are expected. In the first case the pilot tunnel is used to activate gradual stress relief caused by the excavation, so that the development of displacements happens in stages and is thus more controllable. In the second case the pilot tunnel is used to enable the room for the drainage measures to dewater the rock mass, which is a precondition to treat and improve the rock mass under the controllable conditions.

\section{EXPECTED GEOLOGICAL CONDITIONS IN THE SECOND TUBE}

Following the needs for the main design of the second tube the comprehensive site investigations were carried during the years 2015 and 2016. This information was complemented with very detailed geological mapping, which was carried out during the excavation of the first tube (Budkovič, 1999). As already indicated earlier, the geological conditions in the Karavanke tunnel were difficult and variable, in a sense that geological units are changeable at small distances. The main lithological units, which were found along the tunnel axis were Permian and Carboniferous clastic rocks with limestone lenses; Middle Permian clastic rocks with brecciated and limestone rock and Upper Permian clastic rocks within Triassic development of Carboniferous clastic rock. Main tectonic units developed in directions (E)-(W) are intersected with several, almost vertical, faults in the directions (NE)(SW) and (NW)-(SE)(Geološki zavod Slovenije, 1988).

The prediction of the longitudinal geological section along the second tube is presented in Figure 2. The following geological units are isolated at the section: QMO - Quaternary sediments (chainages $\mathrm{km} \mathrm{7.8+21} \mathrm{to}$ $7.5+53$ ), glacial moraine and weathered rock formations (sand and gravel with silt parties and larger carbonate blocks); ST - Lower Triassic Werfen formation (chainages $\mathrm{km} 7.5+53$ to $6.9+54$ ), built by oolithic limestone, marl limestone and sandstone; $\mathrm{P}$ - Permian layers (chainages $\mathrm{km} 6.9+54$ to $6.1+56$ ) with characteristic Bellerophon formation (dolomit) and Gröden formation (quartz conglomerate, sandstone and slate clay stone), PC - UpperCarboniferous and Lower Permian layers(chainages $\mathrm{km} 6.1+56$ to $5.1+13$ ) in the form of limestone, quartz conglomerate, sandstone and slate clay stone and T -Upper to Lower Triassic layers (chainages $\mathrm{km} 5.1+13$ to $4.3+76$ ) made of Rabelj formation ( marl, marl-limestone and limestone) and Schlern formation (breccia and dolomite).

Generally, the geotechnical model of the second tube of Karavanke tunnel on the Slovenian side is divided into the five sections: Section 1 - low overburden in moraine and weathered rock material, Section 2 - Lower Triassic Werfen formation with average overburden of $530 \mathrm{~m}$, in which high water inflow is expected, Section 3 - Permian and Carboniferous clastic rock with low capacity and high deformability under average overburden of $680 \mathrm{~m}$ impying squeezing rock conditions; Section 4 - Triassic section with relatively stable conditions but with water bearing fault zone on the end and Section 5 - Triassic dolomite section in stable conditions (Budkovič, 1999). 


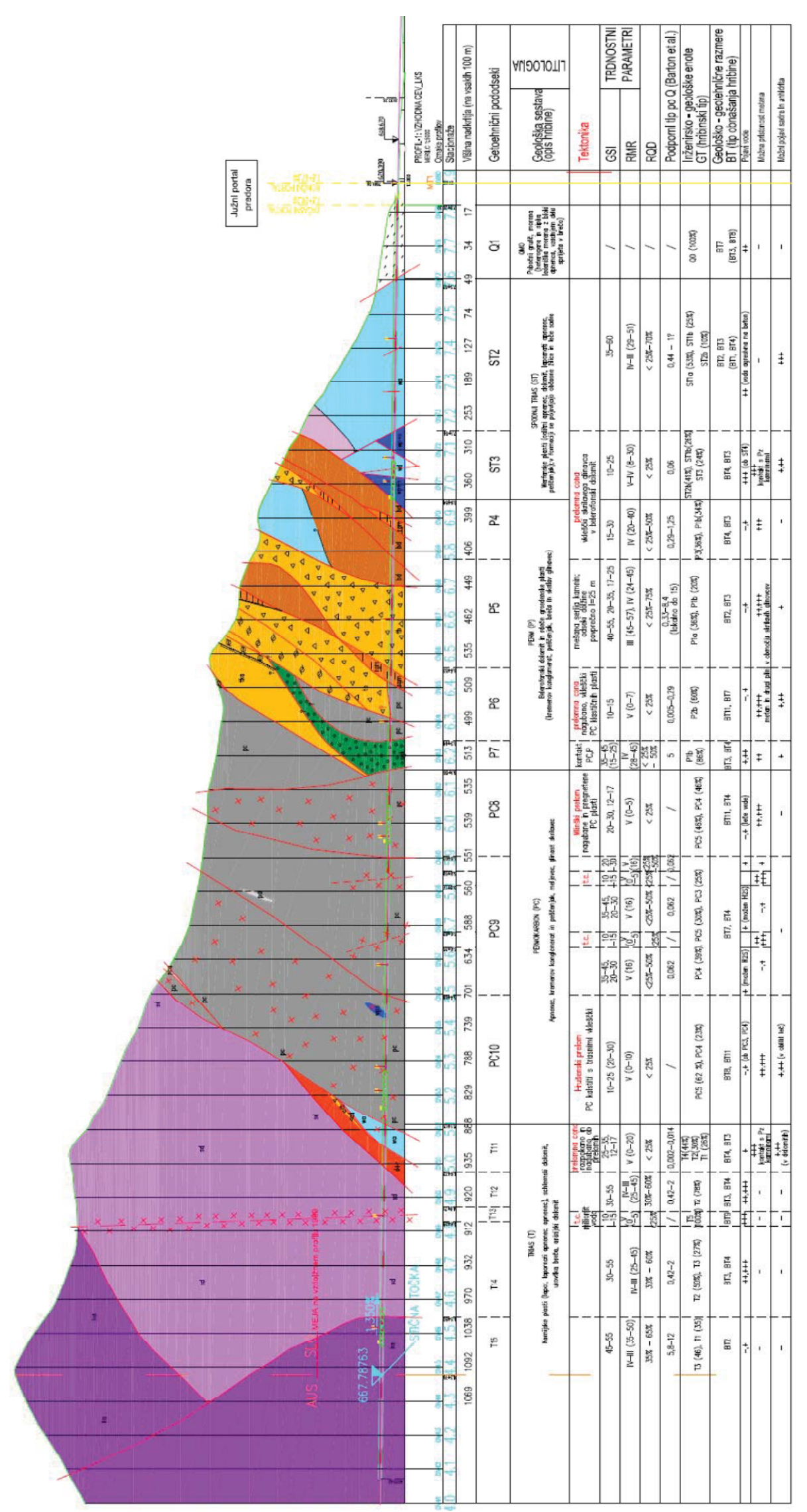

Figure 2. The longitudinal geological section along the second tube with rock mass characterisation 


\section{CONSTRUCTION OF THE FIRST TUBE}

The design of the primary support of the existing tunnel was carried out according to the principles of NATM (New Austrian Tunnelling Method). The profile of the excavation was divided generally into top heading, bench and invert. The invert was not installed along the full length of the tunnel. It was an estimate at the time that the NATM is the adequate method for tunnel construction in difficult ground conditions, which were readily anticipated. On the basis of the devised longitudinal geological section the ground conditions for the Slovenian side of the tunnel were divided into the six categories and each category had its own support system, as shown in Figure 3 (Mikoš, 1991). The additional support system was developed for the loose ground, which was expected in the zone of shallow overburden, in which the moraine material dominated.

The first support category (KRH1) was envisaged for the stable rock mass condition, which actually did not occur during the excavation. The second category $(\mathrm{KRH} 2)$, envisaged for the "broken rock mass "was used only up to $3,6 \%$ of the total length of the tunnel while the category (KRH3) envisaged for " broken, spilling and folded" rock mass was used in $4,6 \%$ of the tunnel. Majority of the tunnel construction, some 40,2\% was carried out in the category (KRH4), which was envisaged for "broken rock mass with rock pressure", while in the fifth category (KRH5) for the "heavily broken rock mass with heavy rock pressure" $25,4 \%$ of the tunnel was executed. The sixth category (KRH6) was used in the conditions of "heavily broken rock mass with heavy rock pressures and strong water inflows", which was undertaken along $17,6 \%$ of the tunnel length. Finally, the

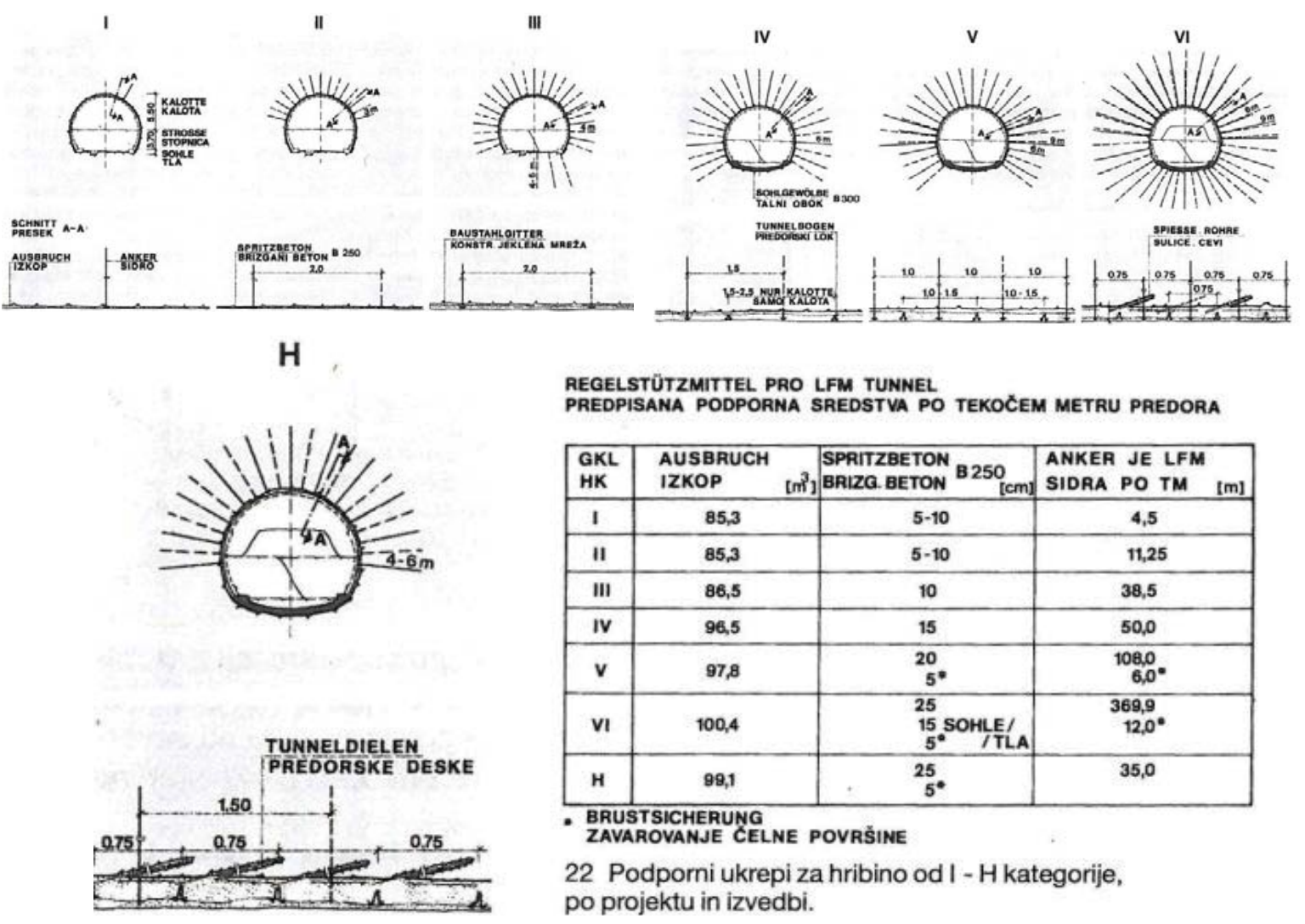

Figure 3. The overview of the excavation categories for the first tube (Mikoš, 1991) support category for the loose ground, which was seen mostly in the zone of shallow overburden, counted for approximately $8,6 \%$ of the tunnel excavation. In general terms, according to the comprehensively written overview of the tunnel construction presented by Mikoš (1991), particular difficulties were caused by the presence of the squeezing rock conditions, the occurrence of methane and the strong water inflows.

The difficulties started immediately during the excavation at shallow overburden in moraine materials, which was extremely heterogeneous. The roof protection was carried out using the $3,5 \mathrm{~m}$ long spears while some top heading instabilities also occurred. The large inflows of water started immediately on the transition into the rock mass material. In the continuation the strong inflow of water of some 100 litres per second was encountered at the chainages of 732 to $746 \mathrm{~m}$. The water inflows were followed by the local instabilities and the wash out of the crushed and lose stone. According to Mikoš (1991), during the further advancing through the reddish gröden layers there were no difficulties. These started again at the transition to Permian and Carboniferous clastic rocks, which occurred at the chainages of around $1450 \mathrm{~m}$. Here the condition of squeezing rock prevailed, which caused the failures of the tunnel lining in the diagonal direction relative to the tunnel axis. The deformations were put under control after the installation of the additional anchors and the construction of the invert. The section through Carboniferous slates was particularly demanding with higher squeezing pressures so that the $50 \mathrm{~cm}$ deformation gaps in the tunnel lining had to be introduced to preserve the integrity of the tunnel support (Budkovič, 1993).
EEGLSTÜTZMITTEL PRO LFM TUNNEL STUT MITEL PAO LFM TUNMEL TEKOCEM METRU PREDORA

\begin{tabular}{|c|c|c|c|}
\hline $\begin{array}{l}\text { GKL } \\
\text { HK }\end{array}$ & $\begin{array}{l}\text { AUSBRUCH } \\
\text { IZKOP }\end{array}$ & $\begin{array}{l}\text { SPRITZBETON } \\
\text { BAIZG. BETON } 250 \\
{[\mathrm{~cm}]}\end{array}$ & $\begin{array}{l}\text { ANKER JE LFM } \\
\text { SIDRA PO TM [m] }\end{array}$ \\
\hline 1 & 85,3 & $5-10$ & 4,5 \\
\hline II & 85,3 & $5-10$ & 11,25 \\
\hline III & 86,5 & 10 & 38,5 \\
\hline IV & 96,5 & 15 & 50,0 \\
\hline v & 97,8 & 20 & 108,0 \\
\hline VI & 100,4 & $\begin{array}{l}25 \\
15 \\
5^{\circ}\end{array}$ & $\begin{array}{r}369,9 \\
12,0^{\circ}\end{array}$ \\
\hline H & 89,1 & 25. & 35,0 \\
\hline \multicolumn{4}{|c|}{$\begin{array}{l}\text { BRUSTSICHERUNG } \\
\text { ZAVAROVANJE CELNE POVRŠINE }\end{array}$} \\
\hline
\end{tabular}


At the chainage $1700 \mathrm{~m}$ the tunnel excavation was fully in Carboniferous clastic rock. Instead of the expected $35 \mathrm{~cm}$ of total convergence movement these were accelerating in the top heading at a rate of around $17 \mathrm{~cm}$ per day (Mikoš, 1991). Large and fast deformations were pulling out the anchors and the anchor plates were sheared off. For this reason a new anchor head was introduced, which allowed for $20 \mathrm{~cm}$ of axial deformation before the full capacity of the anchor was activated. Also the deformation gaps were introduced into the lining so that more of the load was transferred to the rock mass before was taken by the tunnel lining. The extreme deformations were encountered at the transition from sandstone parties within the clastic rocks into the much weaker Carboniferous slates. These movements were at some points up to $150 \mathrm{~cm}$ so that some remedial works on the primary lining were inevitable despite all the measures that were undertaken to prevent this. The occurrence of the high concentration of methane was detected between the chainages $1560 \mathrm{~m}$ and $2600 \mathrm{~m}$. This required a particular safety measures for the work under the methane regime, which additionally slowed down the progression (Mikoš, 1991). The presence of methane was detected by using the pre-drilling procedures, which were systematically used along this difficult section.

Carboniferous section ended at the chainage of $2550 \mathrm{~m}$. The next section was significantly easier featuring limestone and schlern dolomites. The high overburden, which was at this point some $800 \mathrm{~m}$, and the high inflow of water did not caused particular difficulties. By the rule, after the excavation, the inflow of water quickly ceased and the predrilling, which was continuously used also at this section, was an effective measure to instrument the drainage.

These conditions prevailed up to the chainage $3030 \mathrm{~m}$, in which the pre-drilling indicated that an aquifer zone lies ahead featuring extremely high water pressures. The additional boreholes were installed at the head of excavation, but these were clogged almost immediately and it was clear that the water pressure build up behind the top heading would inevitably cause an incontrollable and dangerous failure. At this point the human workforce and the machines were moved far out from the top heading and the failure was caused remotely by the controlled blast. The sudden inflow of huge amount of water flooded the tunnel. There was an estimate that $4500 \mathrm{~m}^{3}$ of the material was washed out and that the initial inflow was some $1 \mathrm{~m}^{3}$ per second (Mikoš, 1991).

Once the inflow of the water became controllable and constant the major remedial works started. Gabions were used to ensure the stability of the locally damaged tunnel lining. The water pressure relieve boreholes were further installed at the head of excavation to enable controllable drainage conditions. Finally, the bypass pilot tunnel of smaller dimensions was built along the deviation of the tunnel axis, which revealed a major fault zone that was channelling the water inflow. More pressure relief boreholes were installed from the bypass pilot tunnel towards the main axis. After the progression through the fault zone the pilot tunnel was re-directed along the tunnel axis and the works advanced within the relatively simple geotechnical conditions with no further delay. At the position of the fault zone, the head of the excavation of the main tunnel was injected and stabilised and the breakthrough of the main tunnel within the fault zone was carried out in fully controllable manner.

The continuation of the excavation up to the state border was relatively undemanding as the last $400 \mathrm{~m}$ of the tunnel construction were carried out within the hard limestone and dolomites with occasional sections of marl and sandstone.

\section{USE OF PILOT TUNNEL METHOD IN THE SECOND TUBE}

Given the complex geological structure and the experience from the construction of the first tube described in the previous sections the following challenges are expected during the construction of the second tube: a) large convergence displacements in the squeezing rock conditions and b) huge inflows of water. Both of these conditions can be partly or fully addressed using the pilot tunnel method, as it will be explained in continuation.

\section{(i) Large convergence displacements}

During the construction of the first tube the large convergence displacements were first encountered in extreme form at the chainage $1450 \mathrm{~m}$ in which there was a transition from Permian to Permian-Carboniferous rock in the form of clay slate structure. The deformations that were measured along the tunnel are shown in Figure 4. As it can be seen in the figure even more extreme deformations, up to $1,5 \mathrm{~m}$ were experienced at the chainage of $1700 \mathrm{~m}$. The trend of high displacements continued along the full length of Permian-Carboniferous section with similar magnitude of deformation (Mikoš, 1991).

The philosophy of the NATM method is based on the notion that the lining needs to be flexible so that majority of the load caused by the relaxation of the initial stresses is taken by the surrounding rock mass. This is very difficult to achieve in the condition of the squeezing rock in which the ratio between the height of overburden and the uniaxial strength of the rock mass is very high. This implicitly leads to high and wide plasticisation of the rock mass around the cavity and premature installation of the tunnel lining will result in the loss of lining integrity.

The measures that are predicted to cope with large convergence displacements under the conditions of squeezing rock include the use of deformation gaps (once they close the lining start taking the load) which are integrated in the lining. They can be made to be load bearing, which can help in controlling the rate of the convergence movements and thus transfer of the force from the rock mass to the tunnel lining.

The next measure is the use of the rock anchors with ductile rods, which enables them to take the full load even after the significant level of deformation. The control of the large convergence displacements can be carried out to a certain extent by the careful sequencing of the excavation of the top heading bench and the invert. The closing of the invert should be carefully chosen once the activation of the lining is nearing to the full capacity. For this purpose the load cells are predicted to be installed in the deformation gaps so that the process can be monitored in real time and the 
adequate decision can be taken on time and within the required tolerances. The typical cross section, in which supporting measures are presented in the zone of squeezing rock conditions, in which the large convergence displacements are expected, is shown in Figure 5

\section{KONVERGENZ-KONVERGENCE H1}

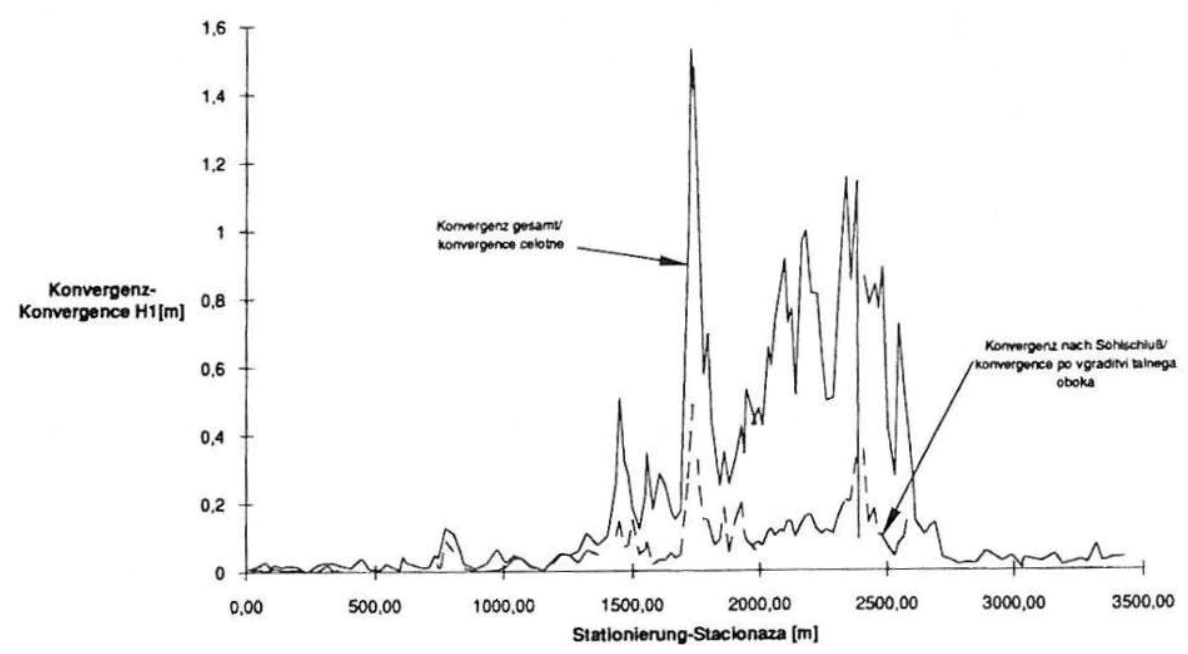

Figure 4. Themagnitude of convergence movement experienced during the construction of the first tube(after Mikoš 1999)

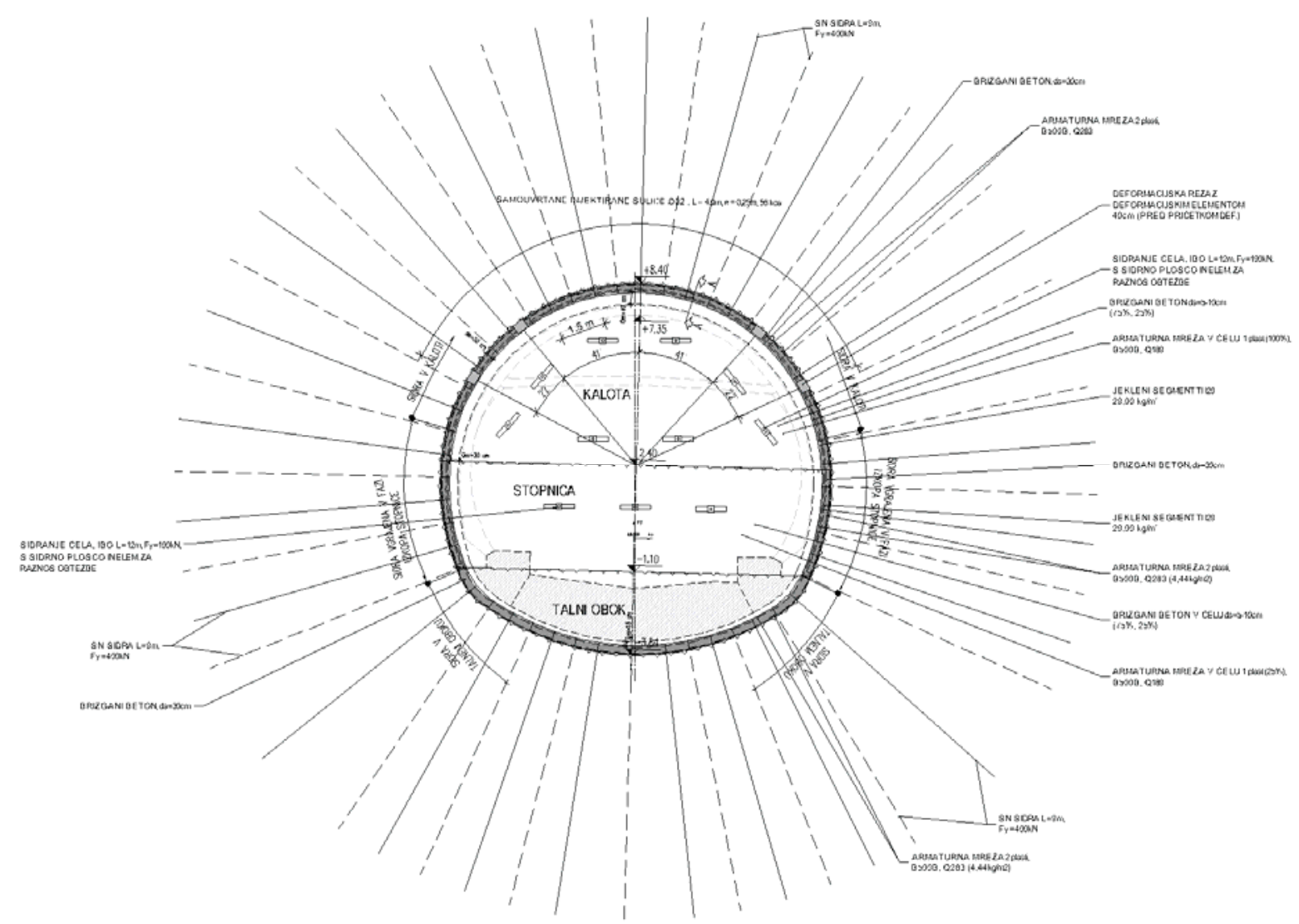

Figure 5. Support system for the second tube for the of squeezing rock conditions 
Finally, if all the measures numbered above are still inadequate to control the displacements in squeezing rock conditions a pilot tunnel can be introduced with an aim to activate gradual stress relief caused by the excavation. By the use of the pilot tunnel the development of the displacements becomes more controllable as the pilot tunnel allows for partial unloading within the future cavity, which is of a smaller diameter and so easier to stabilise. Once the stable conditions are established in pilot tunnel the further treatment and improvement of the rock mass could be carried out to control the final amount of displacements.

The decision to construct a pilot tunnel will depend on the geological conditions currently met in the second tube, in particular on the conditions of efficient drive in terms of displacements caused by squeezing rock, and the risk of possible detrimental influence on the functionality of the existing tube.

\section{(ii) Large inflows of water}

As it was explained before, during the excavation of the first tube the large inflows of water were at some point almost insurmountable obstacle for the construction of the tunnel. The hydrogeological report (IRGO, 2014) based on the new site investigation and the observation of the current state of the drainage in the existing tube located seven aquifers that are relevant for the tunnel. The most water bearing aquifer, which caused the large inflow of water and stopped the excavation of the first tube, is the highly permeable and fissured Schlernian dolomite aquifer that is heavily influenced by the Goliški fault. The aquifer has a free water table and is characterised by the large differences in permeability, around 100 times higher at some locations along the certain parts of the fault zone. This situation enables the channelling of the large quantities of the water so that the water pressures of up to 75 bars can be found at the deep fault layers reaching the elevation of the tunnel.

During the excavation of the first tube the maximum recorded inflow was in the Schlemian dolomite aquifer with some 5000 litres per second (Mikoš, 1991). The other inflows were drained relatively quickly, after three to four months, during the construction of the tunnel. However, after 25 years of the drainage provided by the tunnel the Schlemian dolomite aquifer was not drained. At the moment, it provides with the inflow of some 601 per second (Brenčič, M. \&Poltnig, W., 2008).It is anticipated that the hydrogeological conditions would be much more favourable during the excavation of the second tube in the comparison with the first. The difference between the axis of the tunnels is some 40 to 70 metres so that the drainage system of the tunnel represents some form of the regulated drainage of the aquifers, which can be also felt in the second tube. This is the reason to expect the significantly lower water inflows in the second tube during the excavation.

Treating and improving of the rock mass prior to construction of the main tunnel is the main reason to construct pilot tunnel at the locations of the crossing the aquifers. From the experience of the excavation of the first tube the dewatering of the rock mass can take several weeks prior to re-establishment of the normal working conditions. While the pilot tunnel is used for dewatering, the drive of the main tunnel can continue at the normal pace in front of the pilot tunnel. In this case the decision to use the pilot tunnel will depend on the volumes of the water ingresses that can have a potential

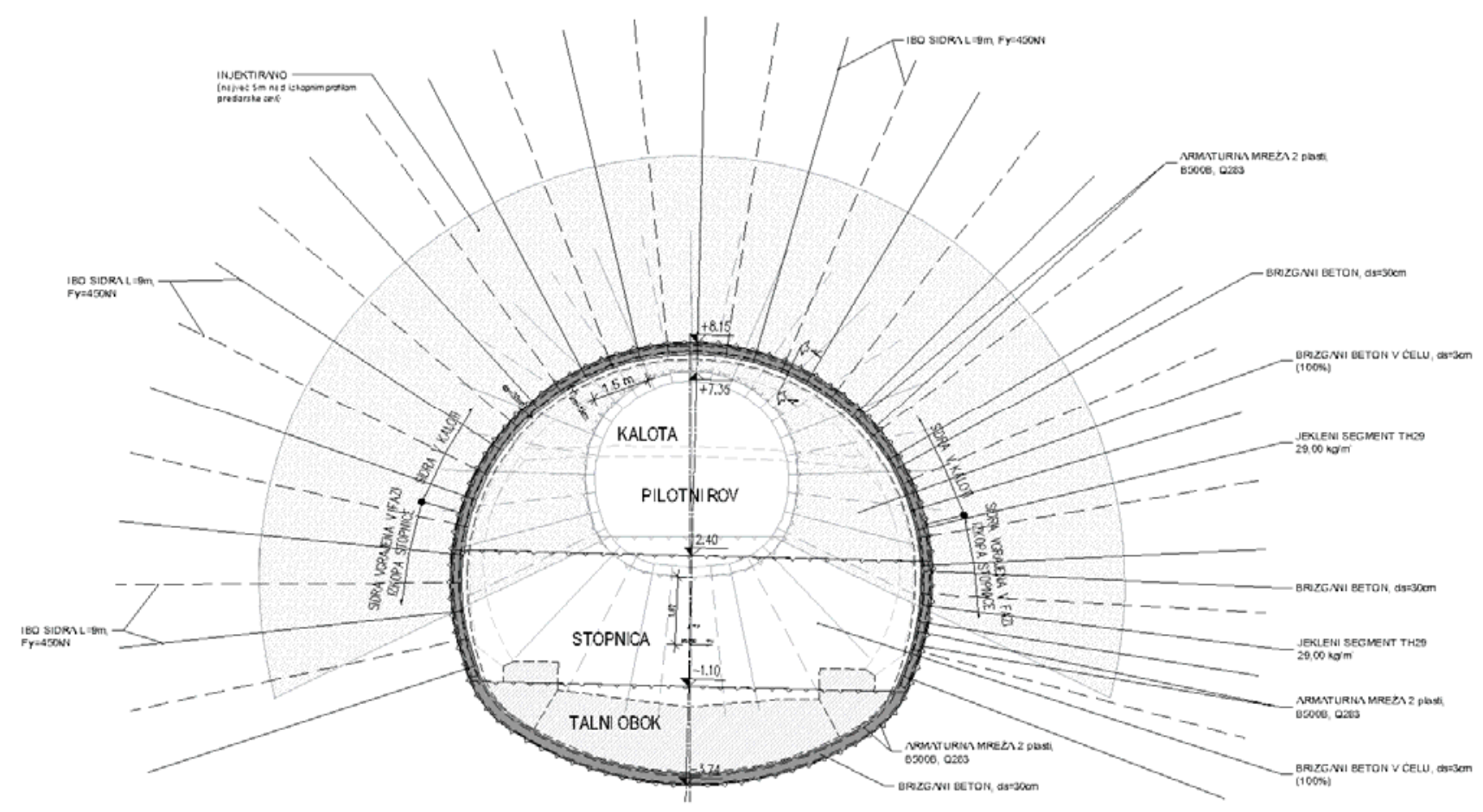

Figure 6. The cross section of the pilot tunnel relative to the main tube. 
to stop the drive. At any rate, the relative cost of the other exploration methods, the cost and the time required for its construction, the value of its benefits and the available funds should all be considered prior to the final decision to use the pilot tunnel method.

Several measures were devised in design stage to control the inflow of the water during the construction of the second tube and to prevent the flooding of the tunnel that occurred during the excavation of the first tube. Predrilling will be used systematically along the excavation of the tunnel. The pressures will be monitored during the pre-drilling and the pressure relief boreholes will be installed if needed.

For the transition through the Schlemian dolomite aquifer, in which the largest ingresses of water are expected the use of a pilot tunnel is predicted. The cross section of the pilot tunnel is shown in Figure 6. The pilot tunnel is designed to occupy approximately one third of the excavation surface in the comparison with the main tube. The utilisation of the pilot tunnel had several purposes. The first one is to enable for the controlled drainage of the Goliški fault so that the efficient pressure-relief boreholes can be installed at the appropriate places. The second purpose is to cause partial stress relief in the area of the fault so that the tunnel lining of the full profile can take lesser load than otherwise. Finally, after the completion of the drainage measures the pilot tunnel can be used to improve the local rock mass in the fault zone and improve the stability of excavation of the main tube. The treatment comprises grouting of the rock mass as it is expected that the rock mass will be weakened by the wash out of the debris caused by the inflow. The longitudinal section of the pilot tunnel within the area of ground improvement is shown in Figure 7.

\section{CONCLUSIONS}

The tunnel Karavanke is some $7,9 \mathrm{~km}$ long single tube motorway tunnel, which is located at European corridor 10 connecting Slovenia and Austria. The construction of the first tube, which took place some 30 years ago, was met with many difficulties. These difficulties are seen as new challenges for the construction of the second tube, which is about to start this year.

The main challenges for the construction of the second tube are the large convergence displacements in squeezing rock conditions and the huge inflows of water. Both items have a potential to undermine the function of the existing tube, which would be under the traffic load all the time. These issues are addressed in the design of the second tube by using the pilot tunnel method. The basic concept of the pilot tunnel method is described in the paper. This method, which is based on a construction of a small-diameter tunnel, which is driven parallel to the axis of a much larger main tunnel is occasionally used in difficult ground conditions. Among the other purposes, the pilot tunnel method can be used for treating or improving the ground prior to construction of the main tunnel.

The applicability of the pilot tunnel method for the excavation of the second tube of Karavanke tunnel is discussed in the paper. General conditions of the excavation of the second tube are presented by geological data, which were derived from the mapping during the construction of the first tube and the additional site investigations. The historical records of the construction of the existing tube are also presented in some detail. The key events during the construction of the first tube are highlighted, including the convergence displacement of up to $80 \mathrm{~cm}$ in the sections of squeezing rock and the large ingress of water experienced during the crossing of the Schlemian dolomite aquifer.

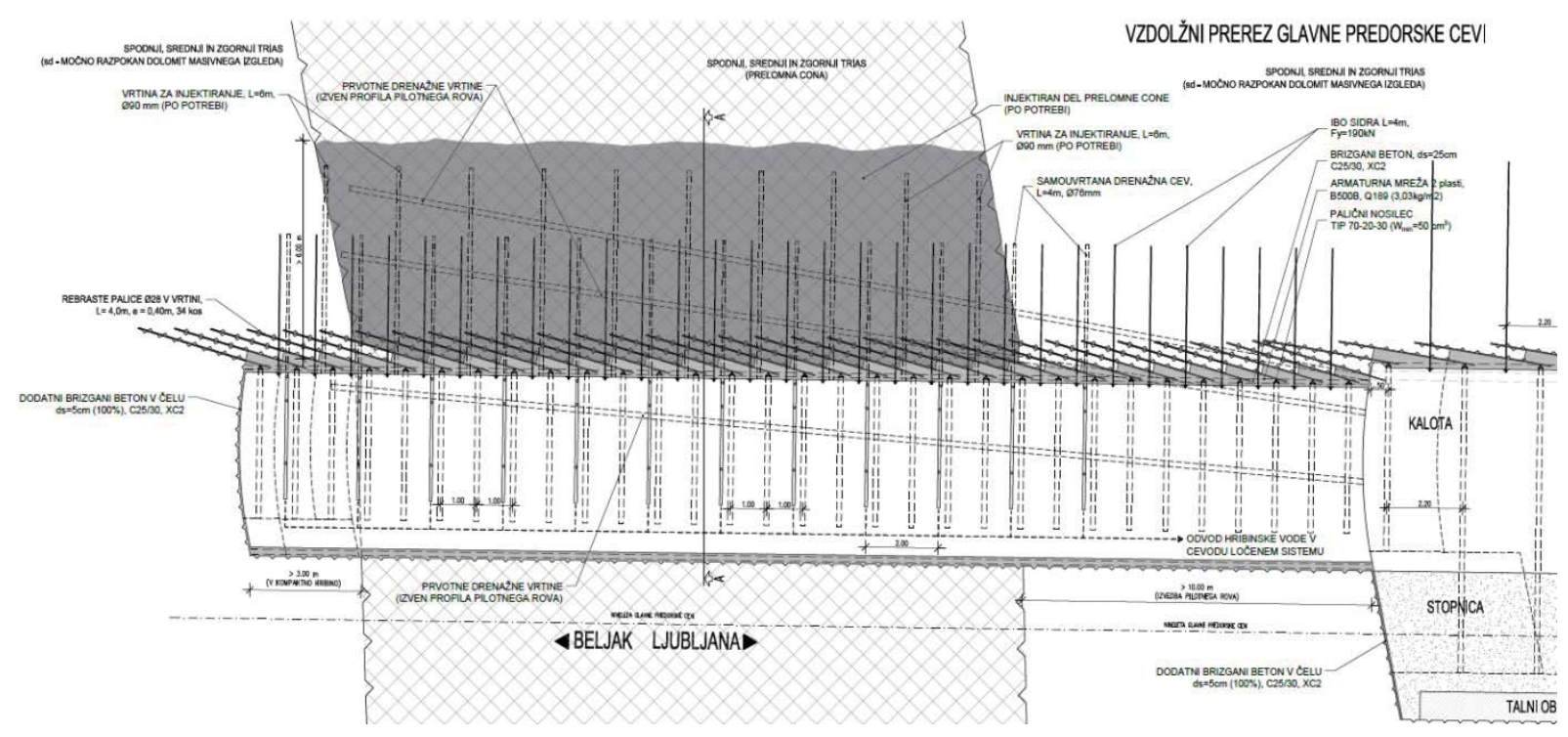

Figure 7. The longitudinal section of the pilot tunnel shown relative to the main tube: drainage and grouting measures are used to improve ground condition in the area of fault. 
The possibilities of the use of the pilot tunnel method are presented on the examples of the design of the second tube of Karavanke tunnel. To control the large convergence displacements in squeezing rock conditions a pilot tunnel can be introduced with an aim to activate gradual stress relief caused by the excavation. By the using this method the development of the displacements becomes more controllable as the pilot tunnel allows for partial unloading within the space of future cavity of the main tunnel. The second and more developed example is related to treating and improving of the rock mass prior to construction of the main tunnel. This would be needed at the locations of the crossing the water bearing aquifers such as Schlemian dolomite aquifer, which effectively stopped the drive of existing tube for several months. While the pilot tunnel would be used for dewatering, the drive of the main tunnel could continue at the normal pace in front of the pilot tunnel. Once the drainage and the improvement of the rock mass concludes the construction of the main tube can be carried out within the controllable conditions without delay.

\section{LITERATURE}

[1] MIKOŠ, B. 1991, Cestni predor Karavanke. Republiška uprava za ceste, Ljubljana in Tauernautobahn AG, Salzburg, Frohnweller Druck GesmbH, april 1991, 65 p.

\section{SUMMARY}

\section{USE OF PILOT TUNNEL METHOD TO OVERCOME DIFFICULT GROUND CONDITIONS IN KARAVANKE TUNNEL}

\section{Vojkan JOVICIC}

The pilot tunnel method was used in design of Karavanke tunnel to address the two main challenges, which are expected during the construction of the second tube. The first challenge is large convergence displacements in squeezing conditions of Permian and Carboniferous clastic rock of low capacity and under high overburden. The second challenge is the large ingresses of water, which are expected at the fault zones when crossing the aquifers, which are numerous and abundant with water. The paper describes the rationale behind the use of pilot tunnel method and gives an overview of the purposes of the installation, including the background information on the applicability of the method in Karavanke tunnel. The conditions for the construction of the Karavanke tunnel are described firstly through geological conditions for the excavation of the second tube and secondly on the basis of historical records obtained during the construction of the first tube, which took place some 30 years ago. Finally, two examples of the design application of pilot tunnel were given for particular sections of the tunnel explaining the usability of the method for the given conditions.

Key words: pilot tunnel method, squeezing rock, large ingress of water, tunnel construction
[2] MIKOŠ, B. 1991, Predor Karavanke, Geologija in geotehnika, Cestni inženiring p.o., Herausgeber, 1991, 72 p.

[3] Kavvadas M. 1999, Exeriences from the construction of the Athens metro project, Proc. $12^{\text {th }}$ European Conference of Soil Mechanincs and Geotechnical Engineering, Amsterdam, June 1999, Invited lecture, Vol 3, pp 1665-1676

[4] IRGO, 2014, Hidrogeološko poročilo za predor Karavanke, Dograditev AC Predora Karavanke Predor, Idejni projekt, oktober 2014, 56 p.

[5] Direktiva Evropskega Parlamenta in Sveta 2004/ 54/ES, Uradni list Evropskeunije, april 2004, 21p.

[6] Brenčič, M. \& Poltnig, W. 2008. Podzemne vode Karavank / Grundwasser der Karawanken. Geološki zavod Slovenije \&J oanneum Research Forschungsgesellschaft, $144 \mathrm{p}$.

[7] Budkovič, T. 1993. Geologija Karavanške gacestnega predora. Magistrskanaloga. Ljubljana, Univerza v Ljubljani, Fakulteta za naravoslovje in tehnologijo: $62 \mathrm{p}$.

[8] Budkovič, T. 1999. Geology of the Slovene Part of the Karavanke Road Tunnel. Gabhandlungen der Geologischen Bundesanstalt, 56/2; p. 35-48.

[9] Jovičić, V., Boštjan, V.: Design of the second tube of Karavanke Tunnel, Proc. of the 7th International Conference "Geotechnics in Civil Engineering", Ed. R. Folić, Šabac, 14-17. Nevember 2017. pp. 37-52.

[10] Geološko poročilo, (Geološki zavod Slovenije, 1988), arh.št. 194.

\section{REZIME}

\section{UPOTREBA METODOLOGIJE PROBNOG TUNELA ZA PREVAZILEŽANJE TEŠKIH USLOVA GRADNJE U TUNELU KARAVANKE}

\section{Vojkan JOVIČıĆ}

Metoda probnog tunela je upotrebljena za projektovanje tunela Karavanke sa ciljem reševanja dva ključna izazova koja se očekuju tokom predstojeće gradnje druge cevi. Prvi izazov predstavlja iskop tunela u uslovima iztiskivanja stenske mase u permo-karbonskoj klastičnoj stenskoj masi niske nosivosti koja se nalazi pod velikim nadslojem. Drugi izazov predstavljaju veliki dotoci vode, koji se očekuju u prelomnim zonama na mestima prolaza kroz vodonosnike, koji su brojni i izuzetno bogati sa vodom. U članku su objašnjeni opšti koncepti za primenu metode probnog tunela kao i upotrebljivost metode za uslove gradnje tunela Karavanke. Očekivani uslovi iskopa tunela su predstavljani pomoću geoloških uslova koji se očekuju tokom gradnje druge cevi a zatim i pomoću uslova iskopa zabeleženih tokom gradnje prve cevi pre 30 godina. Konačno, dva primera projekta primene probnog tunela su prikazana za dva odseka tunela sa ciljem da se predstavi upotrebljivost metodologije za date uslove gradnje.

Ključne reči: metodologija probnog tunela, iztiskivanje stenske mase, veliki dotoci vode, gradnja tunela 